\title{
A redefinition of the modeled responses of mammary glands to once-daily milking
}

\author{
A. G. Rius, ${ }^{1 *}$ G. Levy, ${ }^{1}$ S-A. Turner, ${ }^{1}$ C. V. C. Phyn, ${ }^{1}$ M. D. Hanigan, ${ }^{2}$ and P. C. Beukes ${ }^{1} \dagger$ \\ ${ }^{1}$ DairyNZ Ltd., Private Bag 3221, Hamilton 3240, New Zealand \\ ${ }^{2}$ Department of Dairy Science, Virginia Tech, Blacksburg 24061
}

\section{ABSTRACT}

Milking cows once daily is a management tool that has been implemented to improve physical and financial results of seasonal pasture-based dairy farms. The Molly cow model integrates physiology and metabolism of dairy cattle; however, milk production during shortterm changes in milking frequency (e.g., $1 \times$ milking) is not well represented. The model includes a representation of variable rates of cell quiescence and death. However, the rate constants governing cell death and the return of quiescent to active cells are not affected by milking frequency. An empirical assessment of the problem was conducted, and it was hypothesized that changing the current representation of the rate of cell death in response to short-term $1 \times$ milking would more accurately represent active and quiescent cells and improve predictions of milk production. An extra senescent cell flux was added to account for cell loss during periods of $1 \times$ milking. Additional changes included a gradual decline in the rate of $1 \times$ stimulated senescence during $1 \times$ milking, and a structural change in cell cycling between active and quiescent cells during and after short-term $1 \times$ milking. Data used for parameter estimation were obtained from 5 studies where $1 \times$ milking or different feeding strategies were tested. Parameter estimates of cell loss indicated that $1 \times$ milking would affect a small proportion of quiescent cells to cause extra cell death. This added cell senescence was influenced by the length of $1 \times$ milking such that cell senescence peaked on $\mathrm{d} 1$ of $1 \times$ milking and decayed from that point. The new structure in the model includes a variable rate of cell death in response to $1 \times$ milking and a gradual rate of return of quiescent cells back to the active pool in response to switching to $2 \times$ milking after short-term $1 \times$ milking. Root mean square

Received January 14, 2019

Accepted March 25, 2019.

*Current address: Department of Animal Science, The University of Tennessee, Knoxville, TN 37996.

†Corresponding author: pierre.beukes@dairynz.co.nz errors, mean bias, and slope bias declined by at least $50 \%$ for predictions of energy-corrected milk yield and fat percent. The model showed quantitative agreement with production data from short-term $1 \times$ milking. The accuracy of predictions was improved and the error was reduced by implementing modifications in the model in response to changes in milking frequency.

Key words: modeling, mammary gland, milking frequency

\section{INTRODUCTION}

Milking cows once daily $(1 \times)$ is implemented by seasonal pasture-based dairy farmers to reduce farm costs, improve labor conditions, and improve animal health and reproductive outcomes (Clark et al., 2006). Farmers also use short-term $1 \times$ milking as a managerial strategy to reduce demand for feed during pasture-growth restrictions in early or mid season (e.g., drought or flooding; Kay et al., 2013; Phyn et al., 2014). Compared with cows milked twice daily $(2 \times)$, the decrease in milk production of animals milked $1 \times$ ranges from 7 to $34 \%$. The loss in milk production is partially explained by changes in mammary physiology and mammary cell dynamics (Carruthers et al., 1993; Guinard-Flament et al., 2007; Grala et al., 2011; Kay et al., 2013; Phyn et al., 2014). Hence, a better understanding of the mechanisms underpinning changes in the udder would reveal alternatives to mitigate these losses and maintain production in dairy cows milked $1 \times$.

Current mathematical models of lactation do not properly represent the physiological mechanisms responsible for the losses in milk yield during $1 \times$ milking. For example, the Molly cow model (Baldwin, 1995) is a dynamic mechanistic model representing various aspects of dairy cow metabolism including lactation physiology. The initial representation of mammary cell function used an empirical representation of the combination of cell number and activity per cell. This representation was decoupled and updated using more recent knowledge of mammary physiology and cell dynamics 
by Hanigan et al. (2007, 2009) using representation of mammary cell division and death based on the model of Dijkstra et al. (1997) and the representation of cycling between quiescent and active states according to the model of Vetharaniam et al. (2003). These changes resulted in improved predictions of milk yield (Hanigan et al., 2007) including responses to milking frequencies greater than $2 \times$. However, the revised model does not perform well in predicting production response to $1 \times$ milking, and it does not fully capture changes in milk production in early lactation. These are potential deficiencies that at least in part may be reflective of changes in cell dynamics and overall mammary activity.

The current understanding of the effect of $1 \times$ milking on mammary cell activity is limited. Molecular data from different research groups indicate that $1 \times$ milking increases the expression of genes associated with udder remodeling (i.e., apoptosis and proliferation), and alters expression of genes associated with milk components (Guinard-Flament et al., 2007; Boutinaud et al., 2008; Bernier-Dodier et al., 2010; Grala et al., 2011). Moreover, cessation of milking for $24 \mathrm{~h}$ upregulates expression of genes associated with oxidative stress in anticipation of apoptosis of the mammary cell (Singh et al., 2008). Changes in expression of apoptotic and proliferation genes suggest that the adaptation of mammary cell activity and numbers contribute to reduced production during $1 \times$ milking.

Studies published after the work completed in Molly2007 have indicated a carryover effect of shortterm $1 \times$ milking on milk yield for the remainder of the lactation. This result indicates that changes in cell cycling between active and quiescent states is resulting in greater populations of quiescent cells, which, with a time delay, transfer to senescent cells and thus result in greater cell death rates (Guinard-Flament et al., 2007; Kay et al., 2013; Phyn et al., 2014). The analyses of mammary tissues indicated that apoptotic transcripts (i.e., Bax:Bcl2 and Pycard) were upregulated, and partially explained the long-term losses in milk production (Grala et al., 2011). In agreement with these results, Boutinaud et al. (2008) also reported that short-term $1 \times$ milking upregulated mRNA expression of Bax and Bcl2 genes (7- and 9-fold, respectively). Bernier-Dodier et al. (2010) reported that short-term $1 \times$ milking in mid-lactation cows increased remodeling of mammary tissue. Thus, we suggested that a focus on the representation of cell senescence from the quiescent pool would bring the model in line with experimental observations.

If the representation of mammary cell dynamics captures the biology, then one should be able to resolve the problem by re-parameterization of the existing equations; however, initial attempts to address the problem through parameter adjustment indicated the problem was related to model structure. Ideally, a new representation would be derived to address the problem, but due to the lack of available data, we adopted an empirical approach to characterize the problem and to address the observed deficiencies in performance. This empirical overlay provides a quantitative description of the magnitude and temporal pattern of the deficiency, and a statistical assessment of the significance of the deficiency. Quantitative descriptions of cellular senescence to accommodate $1 \times$ milking in Molly would increase confidence in predictions and optimize strategies for milk production using different milking frequencies. Therefore, the objectives of this work were to identify key parameters that contribute significantly to the representation of mammary kinetics and address some of the shortcomings of $1 \times$ milking in Molly2007. We hypothesized that the changes would improve the accuracy of predictions and reduce error when the representation of cell senescence was represented as a time-dependent effect of $1 \times$ milking.

\section{MATERIALS AND METHODS}

\section{Model Development: Conceptual Changes in Molly}

The base model used for this work was developed by Baldwin (1995) with modifications described in Hanigan et al. (2007, 2009), which will be referred to as Molly2007. The revised model defined herein, which will be referred to as Molly2017, includes conceptual modifications in the representation of death and fluxes of cells in the active and quiescent pools of the udder. The representation of the lactation module in Molly2017 and the modifications in pools and fluxes are depicted in Figure 1.

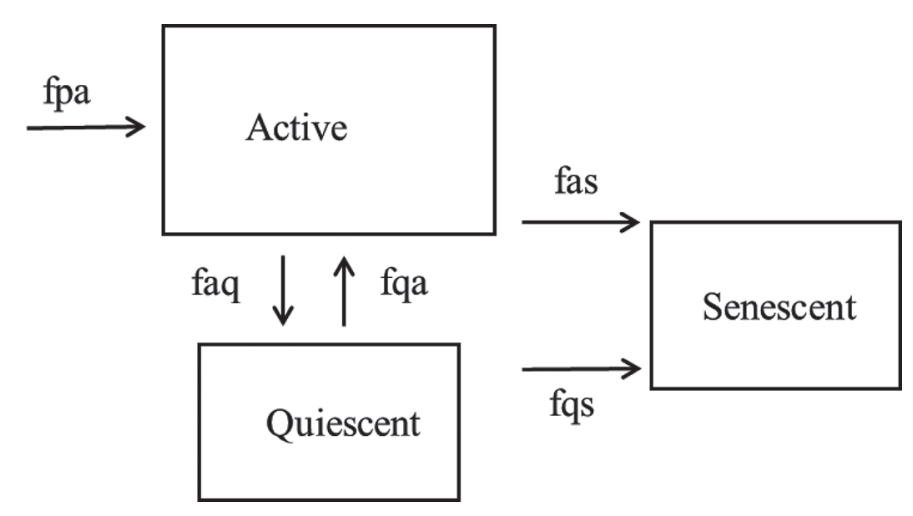

Figure 1. A schematic diagram of the mammary cell module in Molly2017. Boxes represent conceptual pools (active, quiescent, and senescent), and arrows represent fluxes. Fluxes are indicated for cell proliferation to the active pool (fpa), active to quiescent (faq), quiescent to active (fqa), active to senescent (fas), and from quiescent to senescent pools (fqs). 


\section{Total Mammary Cells}

Total mammary cells in the udder are part of the active (i.e., secretory) and quiescent (i.e., resting) pools (Figure 1). The calculation of total cell numbers in Molly is defined by cell proliferation and senescence (cell death) fluxes. This structure allows modification of proliferation rates of cells throughout lactation. Conceptual changes in cell proliferation were not implemented; however, modifications in Molly were implemented to allow alteration of the rate of cell death in response to alterations in milking frequency.

Equation [1] represents cell proliferation to the active pool in Molly:

$$
F_{\text {Pro } \rightarrow \text { Act }}=Q_{\text {Cells }\left(T_{0}\right)} \times\left(k_{\text {Base }}+k_{\text {Pro }} \times e^{-k_{\text {Decay }} \times D I M}\right),
$$

where $Q_{\text {Cells }\left(T_{0}\right)}$ represents the total number of cells at calving, $k_{\text {Base }}$ is the basal rate of cell division, and $k_{P r o}$ is the variable rate constant of cell proliferation, which decays to 0 as lactation progresses based on $k_{\text {Decay }}$.

\section{Changes in Cell Dynamics}

Pools of active or quiescent cells represent alveoli in which the proportion of the former is a driving factor for milk component production. The proportion of total mammary cells that are in the active state, $P_{A c t}$, is defined on a fractional basis in Molly. The differential describing the change in $P_{\text {Act }}$ with respect to $t$ in Molly2007 is indicated below (Hanigan et al., 2007):

$$
\frac{\mathrm{d} P_{\text {Act }}}{\mathrm{d} t}=F_{\text {Quiescent }, \text { Active }}-F_{\text {Active,Quiescent }},
$$

where $F_{\text {Quiescent,Active }}$ and $F_{\text {Active, Quiescent }}$ are the fractional flux of cells from the quiescent pool to the active pool and the fractional flux of active cells to the quiescent pool. The proportion of quiescent cells was derived by difference as follows:

$$
P_{\text {Quiescent }}=1-P_{\text {Act }},
$$

where $P_{A c t}$ was used to calculate the number of active $\left(Q_{A c t}\right)$ and quiescent $\left(Q_{Q u i}\right)$ cells:

$$
\begin{gathered}
Q_{A c t}=P_{\text {Act }} \times Q_{\text {Cells }} \text {, and } \\
Q_{Q u i}=Q_{\text {Cells }}-Q_{\text {Act }} .
\end{gathered}
$$

Quiescent alveoli do not produce significant amounts of milk precursors and they represent about $10 \%$ of the total number of alveoli in the udder (Farr et al., 1996). It is known that the proportion of active and quiescent cells changes throughout lactation because active alveoli can become quiescent or quiescent alveoli can become active as lactation progresses and in response to milk removal (Molenaar et al., 1992; Davis et al., 1999; Hanigan et al., 2007; Singh et al., 2008). The mathematical representation of cell numbers and cell dynamics between these pools must be accurate to minimize errors in predicting milk production and changes in production due to changes in milking frequency. Data indicate that increasing milking frequency increases the cell flux from quiescent to active states in early to mid-lactation (Connor et al., 2008) and prevents active cells from becoming quiescent and apoptotic (Farr et al., 1996; Davis et al., 1999). An attempt was made to capture this in Molly2007 by altering the cycling fluxes between active and quiescent pools as affected by milking frequency (equations [3a] and [3b]; Hanigan et al., 2007):

$$
F_{\text {Quiescent,Active }}=k_{\text {Quiescent,Active }} \times k_{\text {Fill }} \times P_{\text {Quiescent }} \text {, and }
$$

$$
F_{\text {Active,Quiescent }}=P_{\text {Act }} \times \frac{k_{\text {Active,Quiescent }}}{k_{\text {Fill }}},
$$

where $k_{\text {Quiescent,Active }}$ and $k_{\text {Active,Quiescent }}$ in equations [3a] and $[3 \mathrm{~b}]$ are the rate constants, which, together with the pool proportions and the milking frequency factor $\left(k_{\text {Fill }}\right)$, drive the fluxes between the quiescent and active pools. The milking frequency factor represents udder fill changes and assumes a value of 1 with continuous milking and a value of less than 1 for intermittent milking (Hanigan et al., 2007). In Molly2007, cell death (apoptosis/senescence) was represented as a function of the total number of mammary cells at time $t$, and the rate constant of cell death at any point in time $(t)$, where $t$ can be substituted by DIM. Milking frequency had no effect on the rate constant of cell death. This was hypothesized as limiting Molly2007 to accurately predict yields of milk and milk components throughout periods of altered milking frequency. Therefore, in Molly2017 the flux of cell death (senescence; $F_{S e n}$ ) was revised in equations [4a] and [4b]:

$$
\begin{aligned}
& F_{\text {Sen }}= \\
& Q_{\text {Cells }\left(T_{0}\right)} \times\left(k_{\text {Base }}+k_{\text {Sen }} \times e^{-k_{\text {SenDecay }} \times D I M}\right)+F_{\text {MFSen }}, \text { and }
\end{aligned}
$$


$F_{\text {MFSen }}=Q_{\text {Cells }} \times k_{\text {MaxLoss }} \times k_{\text {LowMFDecay }} \times e^{-k_{\text {LowMFDecay }} \times \text { DILM }}$,

where the constant $k_{\text {Base }}$ represents the base rate of cell turnover. The constant $k_{S e n}$ dictates senescence and decays over time $\left(k_{\text {SenDecay }}\right)$. Cell death diminishes asymptotically to zero as the number of days in milk increases. The introduction of $F_{M F S e n}$ into equation [4a] provides a milking-frequency-dependent senescent flux to increase the rate of transfer of active and quiescent cells to the senescent pool during $<2 \times$ milking in Molly2017. This factor was designed to have an effect when milking frequency $<2 \times$. The calculation of the total number of cells $\left(Q_{\text {Cells }}\right)$ as a direct function of DIM was adjusted accordingly to accommodate change in cell death associated with milking frequency. The constant $k_{\text {MaxLoss }}$ in equation [4b] represents the maximum proportion of cells that could be subjected to extra senescence. The constant $k_{\text {LowMFDecay }}$ controls the rate of diminishing cell flux in $F_{M F S e n}$. The term DILM captures time expressed as days in low milking frequency $(<2 \times$ milking). Days in low milking frequency is expressed in terms of $1 \times$ milking; for example, $20 \mathrm{~d}$ of $1.5 \times$ milking is equivalent to $10 \mathrm{~d}$ on $1 \times$ milking. Equation [4b] calculates rates of extra senescence where the integral of $F_{M F S e n}$ grows asymptotically toward $Q_{\text {Cells }} \times k_{\text {MaxLoss }}$ and could get near it only if $1 \times$ milking was applied from calving to dry off.

$$
\begin{gathered}
F_{\text {Active,Senescent }}=F_{\text {Sen }} \times \frac{Q_{A c t}}{Q_{A c t}+Q_{Q u i}}, \text { and } \\
F_{\text {Quiescent,Senescent }}=F_{\text {Sen }} \times \frac{Q_{Q u i}}{Q_{A c t}+Q_{Q u i}} .
\end{gathered}
$$

Equations [5a] and [5b] were newly introduced into Molly2017 to capture the effect of size of active and quiescent pools on cell fluxes to senescence. The best fit to data was achieved when both pools had equal opportunities of senescence. Furthermore, inspection of observed data showed that the effect of reduced milking frequency on milk production had a short time lag, whereas increased milking frequency had a longer time lag before the active cell pool and milk production recovered. Thus, equation [3a] required some modification in Molly2017 to accommodate this difference in time lag:

$$
F_{\text {Quiescent }, \text { Active }}=k_{\text {Quiescent }, \text { Active }} \times Q_{Q u i} \times\left(M F_{\text {lag }} / 2\right)^{k_{M F Q u i A c t}},
$$

where the term $M F_{\text {lag }}$ represents more accurately the lag response due to changes in milking frequency. The lag response to a reduction in milking frequency is 1 to $2 \mathrm{~d}$, whereas the lag response to an increase in milking frequency was estimated at 5 to $10 \mathrm{wk}$. The constant $k_{M F Q u i A c t}$ controls the breed-specific response (milk yield loss) due to decreasing milking frequency (e.g., the yield loss is smaller in Jersey than Holstein-Friesian cows). Overall, this equation better represents the immediate (i.e., daily) and long-term (i.e., weekly) changes in milk yield in response to change in milking frequency.

\section{Model Parameterization: Observed Data, Key Parameters, and Parameterization Process}

Data reported in the studies of Aston et al. (1995), Clark et al. (2006), Macdonald et al. (2008), Kay et al. (2013), and Phyn et al. (2014) were used for parameterization work and to evaluate the model. Aston et al. (1995) conducted 2 experiments to test the effect of 3,6 , and $9 \mathrm{~kg}$ of concentrate supplementation from wk 4 to 22 of lactation in Holstein-Friesian cows that received a base diet of grass silage ad libitum. Clark et al. (2006) studied the effect of milking frequency $(1 \times$ vs. $2 \times$ milking per $\mathrm{d}$ from calving to dry off) on milk yield and composition, lactation length, BW, and BCS over a 4-yr period. Macdonald et al. (2008) compared the effect of genetic strains of Holstein-Friesian of New Zealand origin from the 1970s and 1990s, with Holstein of North American origin with genetics from 1990s on milk production and composition, BW, and BCS. Kay et al. (2013) tested the effect of 2 milking frequencies and 2 feeding levels for 3 wk in early lactation on pasture-based dairy cows. Phyn et al. (2014) conducted a study to test the effect of different milking frequencies and durations in Holstein-Friesian dairy cows. Treatments were cows milked $2 \times$ from calving to dry off (control), cows milked $1 \times$ for 3 wk postpartum and $2 \times$ thereafter, and cows milked $1 \times$ for 6 wk postpartum and $2 \times$ thereafter.

Modifications in Molly were conducted using ACSLXtreme ver. 3.0.2.1 (Aegis Technologies Group, Austin, TX). The parameterization of Molly was conducted using DairyNZ's Whole Farm Model Optimizer (Beukes et al., 2008). The optimizer uses a genetic algorithm (Storn and Price, 1997) that was set to minimize the root mean square error (RMSE) between observed and predicted data sets by varying the parameter values related to lactation and milking frequency. The average of RMSE of the parameterization procedure was $24.4 \%$. This was followed by a cross-validation procedure (Witten and Frank, 2005), where multiple rounds of parameterizations were conducted by excluding a 
different subset of the observed data in each round in a rotational manner. For each round the excluded subset was used for evaluating the optimum parameter set that was obtained for the rest by calculating RMSE. The average RMSE of the cross-validation procedure was $24.6 \%$, indicating a stable predictive error. The standard errors of each parameter were estimated using the methodology reported previously (Efron and Tibshirani, 1986).

\section{RESULTS AND DISCUSSION}

Parameter estimates for the revised lactation cell module in Molly2017 are shown in Table 1. Data fitting and estimates of parameter variability were adequate as indicated by standard deviations of the parameter estimates that were less than half of the estimated value for most parameters (Table 1). Molly2017 generally improved the adequacy of predictions by having lower RMSE, mean bias, and slope bias than Molly2007 for ECM. Root mean square error and slope bias were lower in Molly2017 for both fat and protein yield, but mean bias was higher (Table 2). Improvements are further confirmed by residual plots (Figure 2a,b) showing substantial reductions in ECM residuals for Molly2017 compared with Molly2007. In Molly2017 the changes in active mammary cells (Figure $3 \mathrm{a}$ ) showed the immediate (days) decrease in cell numbers with a reduction in milking frequency $(1 \times)$ compared with $2 \times$ milking from calving. Active mammary cells also showed the longer lag response (weeks) with an increase from $1 \times$ to $2 \times$ milking, and the long-term carry-over effect of $1 \times$ milking after calving on the rest of the lactation. These changes were reflected in the predicted ECM production curves of short-term $1 \times$ milking versus full-lactation $2 \times$ milking from calving (Figure $3 \mathrm{~b}$ ), and resulted in the predicted production curves capturing the observed trends (Figure 3c). This pattern of milk production was in agreement with a previous report comparing $1 \times$ milking with $2 \times$ milking in early lactation where Phyn et al. (2014) showed that temporary $1 \times$ milking had lactation-long negative effects on milk yields. Phyn et al. (2014) showed that during mid and late lactation, cows previously milked $1 \times$ had lower average daily ECM yield ( $-8 \%$ ) than cows continuously milked $2 \times$, and that this effect was still present at wk 32 (224 DIM), contributing to an approximately $10 \%$ reduction in cumulative milk yield by the end of lactation (Phyn et al., 2014).

Two main changes were made in Molly2017 that drive the pattern of active mammary cells and, therefore, milk production in cows milked $<2 \times$. The first change is the inclusion of extra cell death (senescence) from both quiescent and active pools when switching to
Table 1. Parameter estimates for the revised representation of mammary cells in Molly2017

\begin{tabular}{lcc}
\hline Predictor $^{1}$ & Estimate & SD \\
\hline Mammary cells postcalving & 0.0065 & 0.00053 \\
$k_{\text {SenDecay }}$ & 0.203 & 0.0155 \\
$k_{\text {Decay }}$ & 0.887 & 0.1959 \\
$k_{\text {MFQuiAct }}$ & 0.093 & 0.027 \\
Senescence in $1 \times$ milking & 0.0261 & 0.01709 \\
$k_{\text {MaxLoss }}$ & \\
$k_{\text {LowMFDecay }}$ & \\
${ }^{1} k_{\text {SenDecay }}=$ decay in cell senescence over time; $k_{\text {Decay }}=$ decay in cell \\
proliferation over time; $k_{M F Q u i A c t}=$ breed-specific effect on the milking \\
frequency lag response; $k_{\text {MaxLoss }}=$ the maximum proportion of cells \\
that could be subjected to extra senescence; $k_{\text {LowMFDecay }}=$ decay of cell \\
senescence flux due to length of low milking frequency.
\end{tabular}

$<2 \times$ milking, and the second change is incorporating a time lag into the flux of quiescent to active cells when $<2 \times$ is reversed back to $2 \times$ milking. The duration and decay of this extra senescence can be seen in Figure 4 . The effect of this is representing the long-term carryover effect of $<2 \times$ milking that can be seen in the total and active mammary cells being reduced for the duration of the lactation (Figures 5 and 3a). The second intervention is seen in Figure 6 by a sharp increase in the quiescent cell pool when the cow goes onto $<2 \times$ milking, followed by a more gradual re-awakening of quiescent into active cells as $2 \times$ milking is restored. After this recovery, the long-term carry-over effect of $<2 \times$ can also be seen in the quiescent pool by lower cell numbers for the rest of the lactation. The reversibility of the short-term effect of $<2 \times$ milking suggests that most of the loss in milk production is temporary, which is consistent with the results reported by Vetharaniam et al. (2003) and Hanigan et al. (2007). A more recent

Table 2. Validation results for Molly2007 and Molly2017 against trial data from Phyn et al. (2014) where Holstein-Friesian dairy cows were milked $2 \times$ from calving to dry off (control), or milked $1 \times$ for 3 wk postpartum and $2 \times$ thereafter, or milked $1 \times$ for 6 wk postpartum and $2 \times$ thereafter

\begin{tabular}{lcc}
\hline Variable & Molly2007 & Molly2017 \\
\hline RMSE, ${ }^{1} \%$ of the & & \\
observed mean & 16.2 & 5.5 \\
ECM, kg/d & 15.7 & 6.9 \\
Fat, kg/d & 22.7 & 8.4 \\
Protein, kg/d & 6.6 & 1.0 \\
Mean bias, \% of MSPE & 1.8 & 2.8 \\
ECM, kg/d & 37.2 & 61.6 \\
Fat, kg/d & & \\
Protein, kg/d & 30.2 & 0.0009 \\
Slope bias, \% of MSPE & 30.1 & 0.7 \\
ECM, kg/d & 30.9 & 2.9 \\
Fat, kg/d & \\
Protein, kg/d & \\
\hline
\end{tabular}

${ }^{1}$ Root mean square errors are expressed as a percentage of the observed mean. Mean and slope bias are expressed as a percentage of the mean square of the prediction error (MSPE). 
study by Kay et al. (2013) also confirmed the presence of both short- and long-term carry-over effects of $1 \times$ milking.

In developing the senescence equations, the rate constant $k_{\text {SenDecay }}$ was used with an estimated value of 6.5 $\times 10^{-3} \pm 5.3 \times 10^{-4}$. This parameter is greater than reported previously by Dijkstra et al. (1997) for dairy goats, and Val-Arreola et al. (2004) and Hanigan et al. (2007) for dairy cows. Cell senescence is affected by DIM such that senescence has the greatest value at calving but declines as lactation progresses. This decline agrees with previous studies reporting the same trend (Val-Arreola et al., 2004; Hanigan et al., 2007). The senescence equations also required a maximum rate constant $k_{\text {MaxLoss }}$ estimated at $0.093 \pm 0.027$, indicating that if an animal is on full-lactation $1 \times$ milking, a maximum of approximately $9 \%$ of total mammary cells can be lost to senescence over and above the normal rate of loss. The estimate of $k_{\text {LowMFDecay }}$ was $0.0261 \pm$

(a)

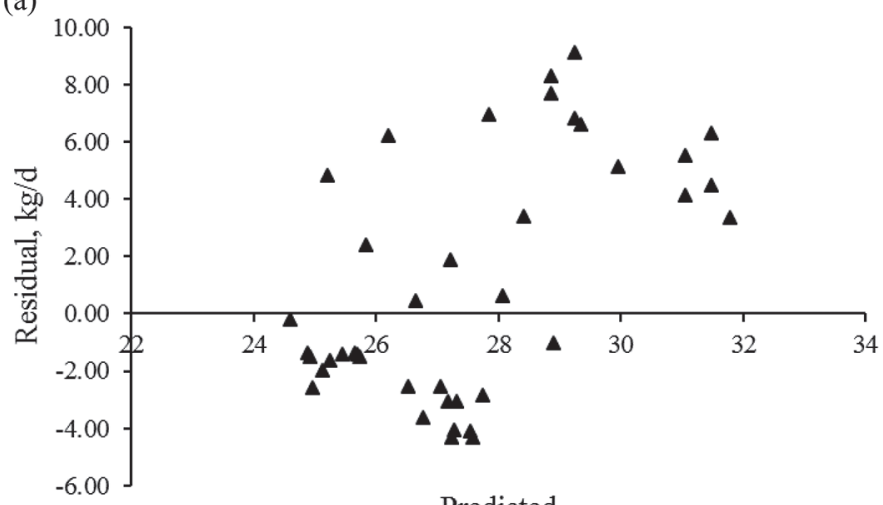

(b)

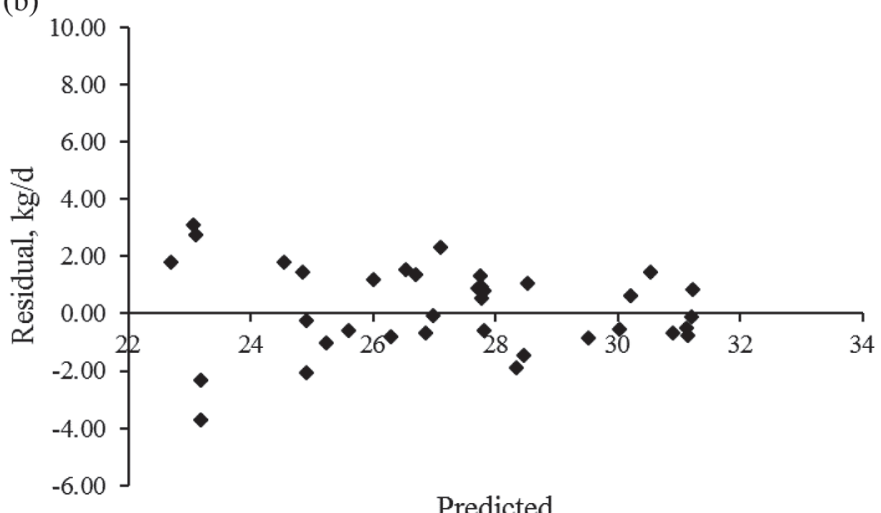

Predicted

Figure 2. Residuals for ECM (kg/d) plotted against predicted values for Molly2007 (a) and Molly2017 (b) using observed data from a milking frequency trial by Phyn et al. (2014) where Holstein-Friesian dairy cows were milked $2 \times$ from calving to dry off (control), or milked $1 \times$ for 3 wh postpartum and $2 \times$ thereafter, or milked $1 \times$ for $6 \mathrm{wk}$ postpartum and $2 \times$ thereafter.
0.01709. This parameter reflects the rate of decay of the negative effects of the length of low milking frequency (days) on cell senescence. However, as this parameter has a standard error of more than $50 \%$ of the estimate, it cannot be considered significant and thus this effect is poorly defined. Clearly, the rate of senescence increases with low milking frequency and thus the change in model structure is justified, but the dampening of this effect is not clear.
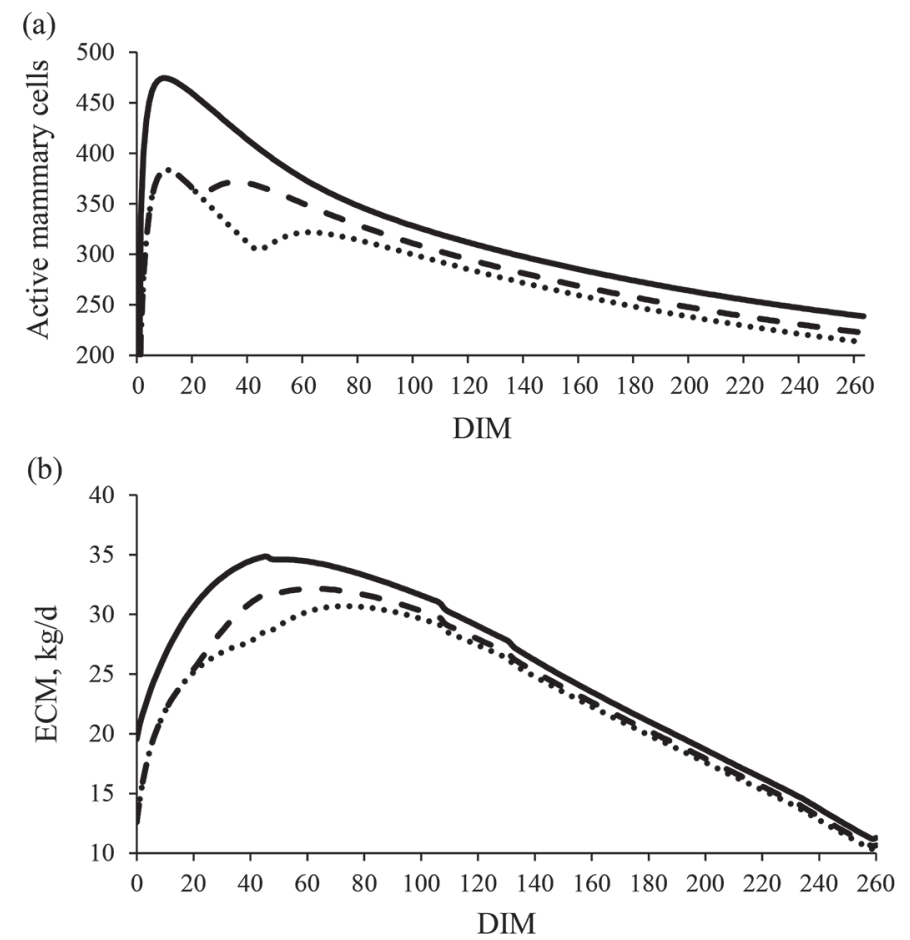

(c)

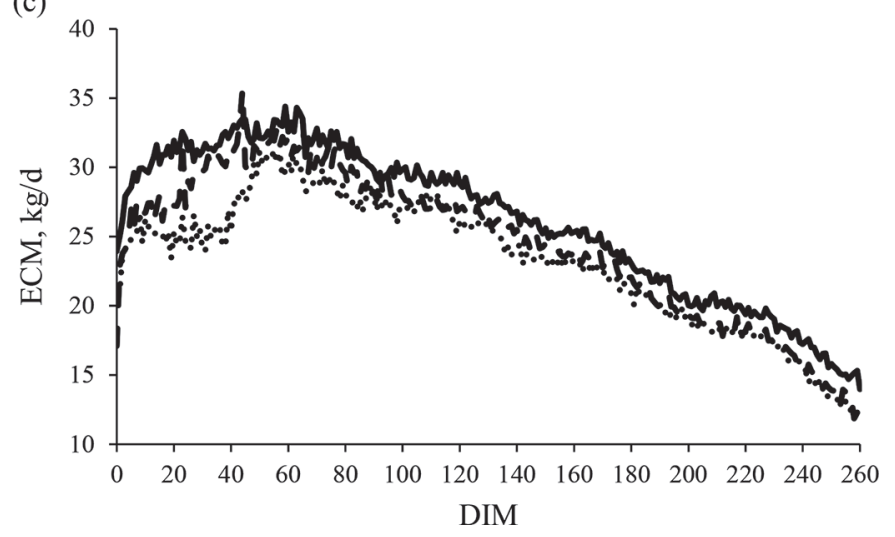

Figure 3. Arbitrary number of active mammary cells (a), ECM production curves predicted by Molly2017 (b), and observed ECM production curves $(c)$ for cows milked twice daily $(2 \times)$ from calving (solid line) or once daily $(1 \times)$ for $3(1 \times 3 \mathrm{wk}$; dashed line) or $6 \mathrm{wk}(1 \times$ $6 \mathrm{wk}$; dotted line) from calving followed by $2 \times$ for the remainder of the lactation. The number of mammary cells is arbitrary and defines the genetic potential of the udder to produce milk (Baldwin, 1995, p. 480). 


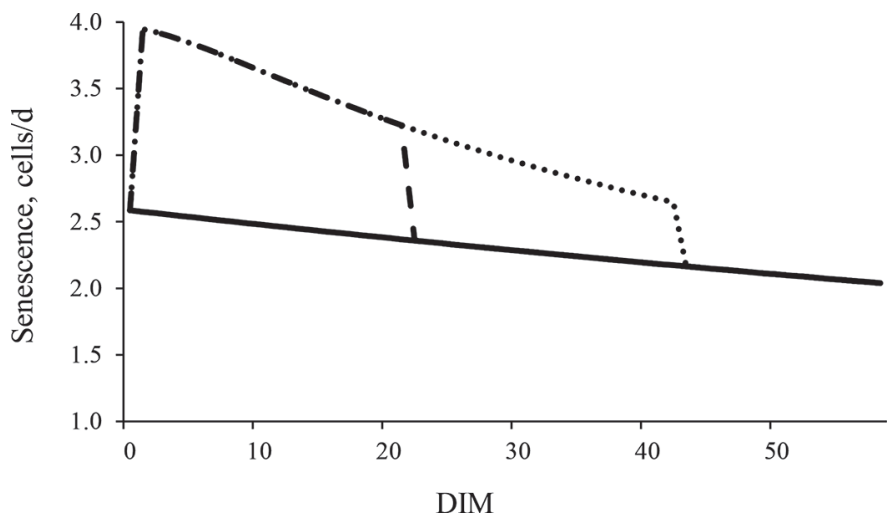

Figure 4. Arbitrary senescence rate of mammary cells predicted by Molly2017 for cows milked twice daily $(2 \times)$ from calving (solid line) or once daily $(1 \times)$ for $3(1 \times 3 \mathrm{wk}$; dashed line) or $6 \mathrm{wk}(1 \times 6 \mathrm{wk}$; dotted line) from calving followed by $2 \times$ for the remainder of the lactation.

A rate constant from Molly2007 that remained in Molly2017, $k_{\text {Decay }}$, reflecting the decay of increased mammary cell proliferation after calving, was estimated as $0.203 \pm 0.015$, which is half the value reported previously (Hanigan et al., 2007). The smaller rate constant is indicative of growth of total cell numbers until d 9 postpartum, compared with the value of 0.44 found by Hanigan et al. (2007) that results in a cessation of cell growth by d 6 postpartum with a $5 \%$ increase in cell numbers after parturition. Our derived value aligns with the value derived by Val-Arreola et al. (2004) from milk production data of dairy cattle.

In summary, the modifications to the model captured changes in cell dynamics during $1 \times$ milking. The gradual rate of return from quiescent to active pool in response to switching back to $2 \times$ milking after shortterm $1 \times$ milking and the overall reduction in cell number after short-term $1 \times$ milking improved the structure of the model and reduced errors of predictions.

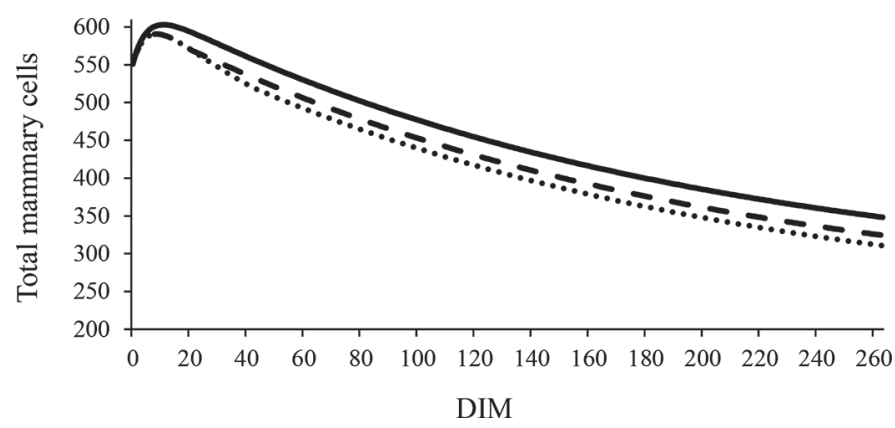

Figure 5. Arbitrary number of total mammary cells predicted by Molly2017 for cows milked twice daily $(2 \times)$ from calving (solid line) or once daily $(1 \times)$ for $3(1 \times 3 \mathrm{wk}$; dashed line) or $6 \mathrm{wk}(1 \times 6 \mathrm{wk}$; dotted line) from calving followed by $2 \times$ for the remainder of the lactation.

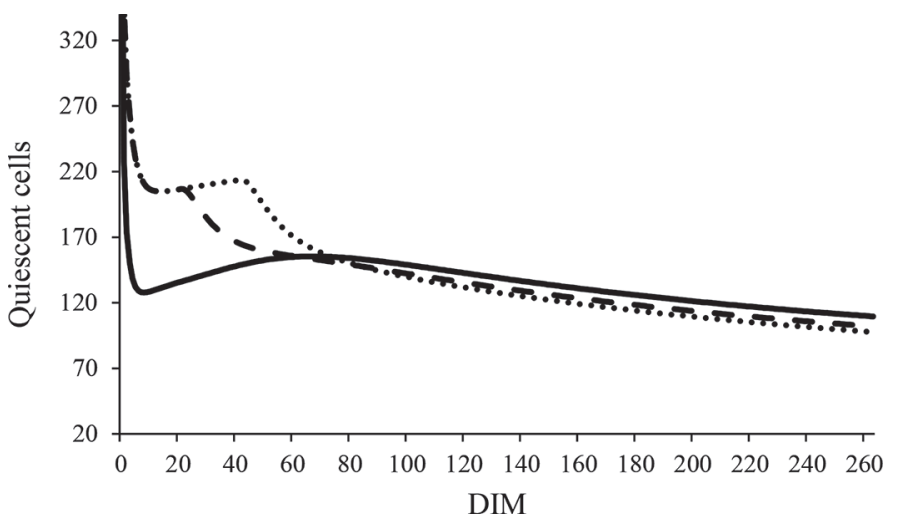

Figure 6. Arbitrary number of total quiescent cells predicted by Molly2017 for cows milked twice daily $(2 \times)$ from calving (solid line) or once daily $(1 \times)$ for $3(1 \times 3 \mathrm{wk}$; dashed line) or $6 \mathrm{wk}(1 \times 6 \mathrm{wk}$; dotted line) from calving followed by $2 \times$ for the remainder of the lactation.

\section{ACKNOWLEDGMENTS}

The authors thank B. Dow (DairyNZ, Hamilton, New Zealand) for her contribution. This work was supported by the New Zealand Ministry of Business, Innovation and Employment, and New Zealand dairy farmers through DairyNZ Incorporated (Hamilton, New Zealand). M. D. Hanigan was partially funded by DairyNZ.

\section{REFERENCES}

Aston, K., J. D. Sutton, and W. J. Fisher. 1995. Milk production from grass silage diets: Strategies for concentrate allocation. Anim. Sci. 61:465-480.

Baldwin, R. L. 1995. Modeling Ruminant Digestion and Metabolism. Chapman and Hall, London, UK.

Bernier-Dodier, P., L. Delbecchi, G. F. Wagner, B. G. Talbot, and P. Lacasse. 2010. Effect of milking frequency on lactation persistency and mammary gland remodeling in mid-lactation cows. J. Dairy Sci. 93:555-564.

Beukes, P. C., C. C. Palliser, K. A. Macdonald, J. A. S. Lancaster, G. Levy, B. S. Thorrold, and M. E. Wastney. 2008. Evaluation of a whole-farm model for pasture-based dairy systems. J. Dairy Sci. 91:2353-2360.

Boutinaud, M., M. B. Chedly, E. Delamaire, and J. Guinard-Flament. 2008. Milking and feed restriction regulate transcripts of mammary epithelial cells purified from milk. J. Dairy Sci. 91:988-998.

Carruthers, V. R., S. R. Davis, A. M. Bryant, H. V. Henderson, C. A. Morris, and P. J. Copeman. 1993. Response of Jersey and Friesian cows to once a day milking and prediction of response based on udder characteristics and milk composition. J. Dairy Res. 60:1-11.

Clark, D. A., C. V. C. Phyn, M. J. Tong, S. J. Collis, and D. E. Dalley. 2006. A systems comparison of once-versus twice-daily milking of pastured dairy cows. J. Dairy Sci. 89:1854-1862.

Connor, E. E., S. S. Siferd, T. H. Elsasser, C. M. Evock-Clover, C. P. Van Tassell, T. S. Sonstegard, V. M. Fernandes, and A. V. Capuco. 2008. Effects of increased milking frequency on gene expression in the bovine mammary gland. BMC Genomics 9:362.

Davis, S. R., V. C. Farr, and K. Stelwagen. 1999. Regulation of yield loss and milk composition during once-daily milking: A review. Livest. Prod. Sci. 59:77-94.

Dijkstra, J., J. France, M. S. Dhanoa, J. A. Maas, M. D. Hanigan, A. J. Rook, and D. E. Beever. 1997. A model to describe growth patterns of the mammary gland during pregnancy and lactation. J. Dairy Sci. 80:2340-2354. 
Efron, B., and R. Tibshirani. 1986. Bootstrap methods for standard errors, confidence intervals, and other measures of statistical accuracy. Stat. Sci. 1:54-75.

Farr, V. C., K. Stelwagen, L. R. Cate, A. J. Molenaar, T. B. McFadden, and S. R. Davis. 1996. An improved method for the routine biopsy of bovine mammary tissue. J. Dairy Sci. 79:543-549.

Grala, T. M., C. V. C. Phyn, J. K. Kay, A. G. Rius, M. D. Littlejohn, R. G. Snell, and J. R. Roche. 2011. Temporary alterations to milking frequency, immediately post-calving, modifies expression of milk synthesis and apoptosis genes in the mammary gland. NZ Soc. Anim. Prod. 71:3-8.

Guinard-Flament, J., E. Delamaire, P. Lamberton, and J. L. Peyraud. 2007. Adaptations of mammary uptake and nutrient use to once-daily milking and feed restriction in dairy cows. J. Dairy Sci. 90:5062-5072.

Hanigan, M. D., C. C. Palliser, and P. Gregorini. 2009. Altering the representation of hormones and adding consideration of gestational metabolism in a metabolic cow model reduced prediction errors. J. Dairy Sci. 92:5043-5056.

Hanigan, M. D., A. G. Rius, E. S. Kolver, and C. C. Palliser. 2007. A redefinition of the representation of mammary cells and enzyme activities in a lactating dairy cow model. J. Dairy Sci. 90:38163830 .

Kay, J. K., C. V. C. Phyn, A. G. Rius, S. R. Morgan, T. M. Grala and J. R. Roche. 2013. Once-daily milking during a feed deficit decreases milk production but improves energy status in early lactating grazing dairy cows. J. Dairy Sci. 96:6274-6284.

Macdonald, K. A., G. A. Verkerk, B. S. Thorrold, J. E. Pryce, J. W. Penno, L. R. MacNaughton, L. J. Burton, J. A. S. Lancaster, J. H. Williamson, and C. W. Holmes. 2008. A comparison of three strains of Holstein-Friesian grazed on pasture and managed under different feed allowances. J. Dairy Sci. 91:1693-1707.

Molenaar, A. J., S. R. Davis, and R. J. Wilkins. 1992. Expression of alpha-lactalbumin, alpha-s1-casein, and lactoferrin genes is heterogeneous in sheep and cattle mammary tissue. J. Histochem. Cytochem. 40:611-618.

Phyn, C. V. C., J. K. Kay, A. G. Rius, S. R. Morgan, C. G. Roach, T. M. Grala, and J. R. Roche. 2014. Temporary alterations to postpartum milking frequency affect whole-lactation milk production and the energy status of pasture-grazed dairy cows. J. Dairy Sci. 97:6850-6868.

Singh, K., S. R. Davis, J. M. Dobson, A. J. Molenaar, T. T. Wheeler, C. G. Prosser, V. C. Farr, K. Oden, K. M. Swanson, C. V. C. Phyn, D. L. Hyndman, T. Wilson, H. V. Henderson, and K. Stelwagen. 2008. cDNA microarray analysis reveals that antioxidant and immune genes are upregulated during involution of the bovine mammary gland. J. Dairy Sci. 91:2236-2246.

Storn, R., and K. Price. 1997. Differential evolution - A simple and efficient heuristic for global optimization over continuous spaces. J. Glob. Optim. 11:341-359.

Val-Arreola, D., E. Kebreab, J. Dijkstra, and J. France. 2004. Study of the lactation curve in dairy cattle on farms in central Mexico. J. Dairy Sci. 87:3789-3799.

Vetharaniam, I., S. R. Davis, T. K. Soboleva, P. R. Shorten, and G. C. Wake. 2003. Modeling the interaction of milking frequency and nutrition on mammary gland growth and lactation. J. Dairy Sci. $86: 1987-1996$.

Witten, I. H., and E. Frank. 2005. Data Mining: Practical Machine Learning Tools and Techniques. Morgan Kaufmann, Burlington, MA. 